\title{
EVALUATION OF DROUGHT TOLERANCE IN WHEAT (TRITICUM AESTIVUM L.) CULTIVARS AT EARLY SEEDLING STAGE USING POLYETHYLENE GLYCOL INDUCED OSMOTIC STRESS.
}

\author{
A. A. Abro ${ }^{1,3^{*}}$, S. Memon ${ }^{1}$, S. A. Abro, ${ }^{1,2}$, E. K. Sam ${ }^{1,3}$, Ru-yu He $^{1,3}$, M. H. Rind ${ }^{1}$, S. Memon ${ }^{1}$, Z. Solangi ${ }^{1}$, T.

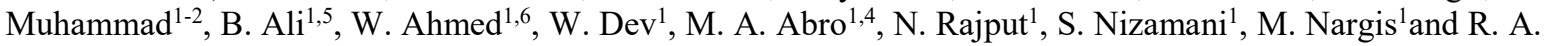 \\ Kumbhar ${ }^{1}$. \\ 1,Department of Plant Breeding \& Genetics, Faculty of Crop Production, Sindh Agriculture University, Tandojam, Pakistan. \\ ${ }^{1,2}$ Department of Soil Science, Faculty of Crop Production, Sindh Agriculture University Tandojam, Pakistan. \\ ${ }^{1,3}$ Maize Research Institute, Sichuan Agricultural University, Wenjiang, Chengdu, Sichuan, China. \\ ${ }^{1,4}$ Department of Plant Protection, Faculty of Crop Protection, Sindh Agriculture University, Tandojam, Pakistan \\ 1,5 Department of Plant Breeding \& Genetics, Faculty of Crop Production Sciences, The University of Agriculture \\ Peshawar, Pakistan. \\ ${ }^{1,6}$ Department of Horticulture, Faculty of Crop Production, Sindh Agriculture University Tandojam, Pakistan. \\ Corresponding Author Email: aamirabrahim@gmail.com
}

\begin{abstract}
Drought is a grave concern due to changing climate phenomenon which drastically affects wheat production throughout the world. Screening drought tolerant varieties of wheat are important for ameliorating productivity of water scarce areas. An experiment was conducted at physiology division Nuclear Institute of Agriculture Tandojam (Latitude: 25.433 Longitude: 68.533) Sindh, Pakistan during 2016-2017. Treatment included a factorial combination using a completely randomized design (CRD) with three replications. Six wheat cultivars (cv. cultivars IBWSN-1010, IBWSN-1025, TD-1, ESW-9525, Khirman and Chakwal-86) were investigated for their response at seedling stage under different water stress treatments (T-1 0, T-2 $-0.5, \mathrm{~T}-3-0.75$ and T-4 $-1.0 \mathrm{MPa})$ in controlled conditions. The results of experiments with reference to cultivars revealed that cultivar Khirman \& IBWSN-1010 showed maximum shoot length (17.33 and 16.68 $\mathrm{cm})$, while the cultivar Khirman and TD-1 showed maximum root length $(10.02$ and $8.67 \mathrm{~cm})$, shoot fresh weight $(34.46$ g $10^{-1}$ shoots), root fresh wt. (71.76 g 10 $0^{-1}$ shoots), shoot dry wt. (13.55 g $10^{-1}$ shoots), root dry wt. (13.62 $\mathrm{g} 10^{-}$ ${ }^{1}$ roots), while the cultivar IBWSN-1010 observed more chlorophyll contents $(0.27 \mathrm{mg} \mathrm{g} 1$ fresh wt $)$ and ionic contents $\left(\mathrm{K}^{+}\right.$ and $\mathrm{Ca}^{+}$, and $\mathrm{K}^{+} / \mathrm{Ca}^{+}$ratio)(1.05, 1.03 and $\left.0.93 \%\right)$. Among all the wheat cultivars tested Khirman and IBWSN-1010 are tolerant cultivar sand have the potential to perform better under drought conditions, whereas IBWSN-1025 and Chakwal-86 were moderately tolerant under water stress conditions. Moreover, the cultivars i.e. TD-1 and ESW-9525 are the sensitive cultivars under drought environment. It may be concluded from present in-vitro studies that osmotic stress significantly reduced the shoot/root length fresh and dry weight in all six wheat cultivars. The maximum reduction $(\mathrm{P} \leq 0.05)$ was found at higher osmotic stress induced by PEG-6000 (-1.0 MPa).
\end{abstract}

Keywords: Drought, Seedling, Germination, Polyethylene glycol, Chlorophyll, Wheat.

https://doi.org/10.36899/JAPS.2020.4.0111

Published online April 25, 2020

\section{INTRODUCTION}

Wheat (Triticum aestivum L.) is a staple food for more than $35 \%$ of the world population and it is also the first grain crops in most of developing countries (Metwali et al., 2011). Abiotic stress, especially drought stress is a worldwide problem, seriously constraining global crop production (Pan et al., 2002), commonly reduces average yield for many crop plants by more than $50 \%$ (Wang et al., 2003; Bayoumi et al., 2008). The high yield of plant in sufficient irrigated conditions is not necessarily related to high yield under drought stress (Jajarmi et al., 2009). Understanding of plant responses to drought is a fundamental part of developing stress-tolerant varieties
(Oneto et al., 2016). Extreme water shortage causes considerable physiological, metabolic and morphological changes in plant, and ultimately reduces crop yield and quality (Maqsood et al., 2012). In most of developing countries, wheat is mainly grown on rainfed lands without supplementary $(590 \mathrm{~mm})$ irrigation About $37 \%$ of land area in these countries consists of semiarid environments in which available moisture constitutes a primary constraint to wheat production (Qayyum et al., 2011). Seed germination and seedling growth characters are extremely important factors in determining yield. Scientists (Dhanda et al., 2004; Rauf et al., 2007; Noorka and Khaliq, 2007) have indicated that seed vigor index and shoot length are among the most sensitive to drought stress, followed by root length and coleoptiles length. 
According to the wheat scientists, seedling growth is influenced under drought stress, but the influence changes from variety to variety. The selection of wheat variety with the best performance under water stress environments could increase the production of rainfed areas. Scientists (Noorka et al., 2013; Ahmad et al., 2014; Ahmed et al., 2017). When plant faces or observe drought condition the amino acids are helpful to complete their life cycle (Abro et al., 2019). Many studies suggested the seed treatments with poly ethylene glycol (PEG6000) that are helpful for alleviating the negative effect of drought stress on plant (Almansouri et al., 2001; Okcu et al., 2005; Kaya et al., 2006 and Iqbal et al., 2007). Selection of drought tolerance at early seedling stage is frequently accomplished using simulated drought induced by chemicals like poly ethylene glycol (PEG6000). Poly ethylene glycol can be used to modify the osmotic potential of nutrient solution culture and thus induce plant water deficit in relatively controlled manner. Researchers (Manoj and Uday 2007; Foito et al., 2009 and Khodarahmpour, 2011) reported that Poly ethylene glycol molecules are inert, non-ionic, and virtually impermeable to cell membranes and can induce uniform water stress without causing direct physiological damage. PEG as a factor causing drought stress by reducing water potential, results in reducing growth of seedling. This effect has been observed to a great extent more in the shoot than primary roots, and it was also suggested that PEG prevent water absorption by seeds, through penetrable ions inside cell by reducing potential results in water absorption at early germination stage (Khajeh et al., 2000; Zhu et al., 2002). The objective of this study was to screen out wheat (Triticum aestivum L.) cultivars under water stress condition at seedling stage using polyethylene glycol PEG 6000 with different concentrations.

\section{MATERIALS AND METHODS}

A laboratory experiment was conducted at physiology division Nuclear Institute of Agriculture Tandojam (Latitude: 25.433 Longitude: 68.533) Sindh Pakistan during 2016-2017. The purpose was to observe effects of water stress, using polyethylene glycol, on seedling growth parameters in wheat; the treatment included a factorial combination using a completely randomized design (CRD) with three replications. In the present study seeds of six cultivars from wheat (IBWSN1010, IBWSN-1025, TD-1, ESW-9525, Khirman and Chakwal-86). Grains of six cultivars were subjected to four stress level of PEG6000 (0.0, -0.5, -0.75, -1.0 Mega Pascal MPa. PEG6000 was prepared by dissolving the required amount of PEG in distilled water at $30^{\circ} \mathrm{C}$. Wheat grains were disinfected with $10 \%$ sodium hypochlorite solution for 30 seconds. After the treatment the grains were washed two times with distilled water. Twenty grains from each cultivar were sown in glass bowls (15 and $10 \mathrm{~cm}$ intensive) in respective treatment from PEG6000. The glass bowls were placed in an incubator under a photoperiod (4.9 $\hat{\mathrm{I}} 1 / 4 \mathrm{~mol} \mathrm{~m}^{-2} \mathrm{~s}^{-1}$ ) for 20 days. Grains were considered germinated when they exhibited radicle extension of $>3 \mathrm{~mm}$. Every 24 hours after soaking, germinated grains were counted daily the experiment to determine following seedling parameters. Shoot length $(\mathrm{cm})$ Root length $(\mathrm{cm})$ Shoot fresh weight (g) Root fresh weight (g) Shoot dry weight (g) Root dry weight $(\mathrm{g})$ and the Ionic contents $(\mathrm{Ca}$ and $\mathrm{K})$ total Chlorophyll content (mg g-1 fresh $\mathrm{wt}$ ), Shoot potassium $\mathrm{K}^{+}(\%)$, Root potassium content $(\%)$, Shoot calcium $\mathrm{Ca}$ $(\%)$, Root calcium (\%), etc., were also observed from shoots and roots of wheat cultivars with help of flame photometer method (Amrutkar et al., 2013).

Statistical analysis: The data recorded were subjected to analysis of variance to discriminate the superiority of treatment means and LSD test were applied following method of Gomez and Gomez (1984) to compare the means.

\section{RESULTS}

In our research trial the ability of the six wheat cultivars under water stressed, induced by PEG (6000) during early seedling stage was assessed under in-vitro environment. Statistical analysis data revealed that different six wheat cultivars depicted performance differently under the different PEG treatments. There was a significant two-way interaction (drought level and cultivars) $(\mathrm{P} \leq 0.01)$ for all seedling parameters. Data pertaining the effect of PEG induced stress on shoot and root length $(\mathrm{cm})$, shoot/root fresh and dry weight, total chlorophyll content (mg g-1 fresh weight), shoot potassium $\mathrm{K}^{+}$, root potassium $\mathrm{K}^{+}$content $(\%)$, shoot calcium $\mathrm{Ca}^{+}(\%)$ and root calcium $(\%)$ is shown in table (1a, $1 \mathrm{~b}$, and $2 \mathrm{a}, 2 \mathrm{~b})$.

Shoot and root length $(\mathbf{c m})$ : Under control conditions, the maximum shoot length was recorded in Khirman followed by, IBWSN-1010 (17.33 and $16.68 \mathrm{~cm})$ as depicted in table.1. Whereas, the maximum root length was recorded in Khirman and ESW-9525 (12.92 and $14.80 \mathrm{~cm})$, moreover, minimum root length was recorded in TD-1 $(5.34 \mathrm{~cm})$. Increasing concentration of osmotic stress reduced shoot and root length of all the wheat cultivars. Maximum reduction was recorded at the highest water stress level (i.e.-1.0 MPa), cultivar Khirman and Chakwal-86 also showed maximum shoot length $(12.56$ and $12.36 \mathrm{~cm})$, followed by TD-1 $(9.68$ $\mathrm{cm})$, IBWSN-1010 $(5.29 \mathrm{~cm})$, and IBWSN-1025 (5.06 $\mathrm{cm}$ ), while minimum shoot length was observed in cultivars ESW-9525 (4.09 cm), respectively. Under highest water stress conditions the cultivar Khirman Chakwal-86 and TD-1showed the maximum root length 
(i.e. $10.02,9.33$ and $8.67 \mathrm{~cm}$ ) followed by cultivars IBWSN-1025 $(5.13 \mathrm{~cm})$, IBWSN-1010 (4.83cm), while minimum root length i.e. $(4.82 \mathrm{~cm})$ was observed in cultivars ESW-9525, respectively. The plant growth related parameters such as root and shoot length, seedlings fresh weight etc., are visualized as major characteristics for screening of drought resistant wheat cultivars (Foito et al., 2009). It is also evident that PEG induced water stress has drastic effect on shoot length of various cultivars. Because artificially osmotic stress cell division necessary for shoot elongation. Similar results are found by the (Almaghrabi et al., 2012) where he found that PEG has effect on shoot length of different wheat cultivars in his research experiment. It may be interpreted that the increasing concentrations of PEG has declining effect on the root length, possibly because of the inhibition of the cell division and elongation. (Chachar et al., 2014) reported that the reduction in the root length under drought stress may due to an impediment of cell division and elongation leading to tender tuberization.

Table.1 a. Mean squares from analysis of variance for various morphological traits of wheat cultivar s at seedling stage under osmotic stress (PEG 6000).

\begin{tabular}{cccccccc}
\hline $\begin{array}{l}\text { Source of } \\
\text { variation }\end{array}$ & DF & Shoot length & Root length & $\begin{array}{c}\text { Shoot fresh } \\
\text { weight }\end{array}$ & $\begin{array}{c}\text { Root fresh } \\
\text { weight }\end{array}$ & $\begin{array}{c}\text { Shoot dry } \\
\text { weight }\end{array}$ & $\begin{array}{c}\text { Root dry } \\
\text { weight }\end{array}$ \\
\cline { 2 - 7 } & & 2 & 0.11 & 2.47 & 66.19 & 129.81 & 2.15 \\
\hline Replications & 3 & $201.97^{* *}$ & $128.22^{* *}$ & $8187.65^{* *}$ & $3041.24^{* *}$ & $135.78^{* *}$ & $38.14^{* *}$ \\
Treatments & 5 & $32.86^{* *}$ & $31.49^{* *}$ & $2298.43^{* *}$ & $1661.08^{* *}$ & $58.23^{* *}$ & $40.70^{* *}$ \\
Cultivar & 15 & $12.24^{* *}$ & $10.93^{* *}$ & $494.15^{* *}$ & $268.92^{* *}$ & $20.68^{* *}$ & $6.76^{* *}$ \\
G x T & 1.45 & 3.99 & 125.3 & 52.79 & 4.74 & 1.49 \\
Error & 40 & & 1.49 &
\end{tabular}

${ }^{* *}=$ significant at $\mathrm{P}<0.01$ probability level, ${ }^{*}=$ Significant at $\mathrm{P}<0.05$ probability level and ns. $=$ Non-significant

Table.2a. Mean squares from analysis of variance for various physiological traits of wheat cultivar s at seedling stage under osmotic stress (PEG 6000).

\begin{tabular}{|c|c|c|c|c|c|c|}
\hline \multirow[b]{2}{*}{ Source of variation } & \multicolumn{6}{|c|}{ Physiological characters } \\
\hline & DF & Total chlorophyll & Shoot $\mathbf{K}^{+}$ & $\operatorname{Root} \mathbf{K}^{+}$ & Shoot $\mathrm{Ca}^{+}$ & Root $\mathrm{Ca}^{+}$ \\
\hline Replications & 2 & 0.00144 & 0.01088 & 0.00111 & 0.01942 & 0.0017 \\
\hline Treatments & 3 & $0.0894^{* *}$ & $2.1955^{* *}$ & $0.32288^{* *}$ & $0.56984^{* *}$ & $0.07825^{*}$ \\
\hline Cultivar s & 5 & $0.30617^{*}$ & $0.74908^{*}$ & $0.14684^{*}$ & $0.65473^{* *}$ & $0.01648^{* *}$ \\
\hline $\mathrm{G} \times \mathrm{T}$ & 15 & $0.00982^{* *}$ & $0.39261^{* *}$ & $0.0604^{* *}$ & $0.07713^{* *}$ & $0.02033^{* *}$ \\
\hline Error & 40 & $0.00354^{*}$ & $0.09586^{* *}$ & $0.01358^{* *}$ & $0.01489^{* *}$ & $0.00325^{*}$ \\
\hline
\end{tabular}

${ }^{* *}=$ significant at $\mathrm{P}<0.01$ probability level, ${ }^{*}=$ Significant at $\mathrm{P}<0.05$ probability level and $\mathrm{ns} .=$ Non-significant

Shoot/root fresh and dry weight $\left(\right.$ g10 $^{-1}$ roots $)$ : The shoot and root fresh weight values were decreased with increasing water stress in all wheat cultivars (table.1) Maximum shoot fresh weight was observed in Khirman (102.86 $10^{-1}$ shoots). Whereas, the minimum shoot fresh weight values were observed in IBWSN-1025(69.33 g 10${ }^{1}$ shoots), moreover, the cultivar IBWSN-1010 reveled more root fresh weight $\left(71.76 \mathrm{~g} 10^{-1}\right.$ shoots $)$ and the minimum root fresh weight observed by cultivar TD-1 (34.46 g $10^{-1}$ shoots) under controlled conditions. The results for shoot and root dry weight is presented in table 1b. Results revealed that significant decrease with increasing water stress. At high water stress condition (1.0 $\mathrm{MPa}$ ) there was comparatively higher reduction in plant biomass with increasing water stress of the growing media. The cultivars Chakwal-86 Khirman and TD-1 showed maximum shoot fresh weight $(57.22,52.87$ and

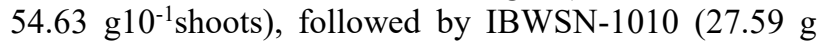
$10^{-1}$ shoots) and IBWSN-1025 (19.73 $\mathrm{g} \mathrm{10}^{-1}$ shoots). While minimum shoot fresh weight (10.82 $\mathrm{g} 10^{-1}$ shoots) was observed in cultivar ESW-9525, respectively.
Root fresh weight: There was decrease in root fresh weight with the increasing in water stress in all wheat cultivars. The decrease was more in $-1.0 \mathrm{MPa}$ as compared to control. Mean values for root fresh weights in three treatments were recorded as 45.35, 39.2, 28.50 and $19.06 \mathrm{~g} 10^{-1}$ roots under control, $-0.5,-0.75$ and -1.0 $\mathrm{MPa}$, respectively. The cultivar IBWSN-1010 showed maximum root fresh weight (71.76 g 10-1 root), followed by Khirman (50.06), IBWSN-1025 (40.55), Chakwal-86

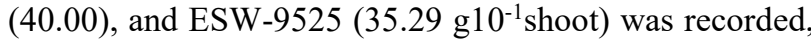
whereas minimum root fresh weight $(34.46$ g10-1 roots) was observed in cultivars TD-1, respectively. Root fresh weight at the highest $-1.0 \mathrm{MPa}$ water stress was observed as maximum in cultivar IBWSN-1010 (i.e. $27.22 \mathrm{~g} 10^{-}$ ${ }^{1}$ roots), followed by TD-1 (25.56), Khirman and Chakwal-86 (25.03 and 13.60 g10 $0^{-1}$ roots). While, the cultivars IBWSN-1025 and ESW-9525 showed minimum

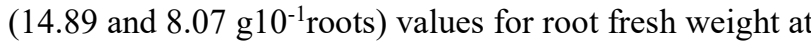
highest osmotic stress, respectively. Our results are in agreement with the results found by (Wei et al., 2013) where he found decreasing trend in shoot and root 
fresh/dry weight. However, it was reported by various researchers that both parameters of shoot/root fresh and dry weight significantly increased shoot and root masses in both cultivars under well watered condition.

Shoot dry weight (g 10 10 $^{-1}$ shoots): Mean values for shoot dry weight in different treatments were recorded as 12.65 , $11.09,10.29$ and $6.61 \mathrm{~g} 10^{-1}$ shoots in different four treatment $\mathrm{s}$ as T1control (0), T2 -0.5 , T3 -0.75 and T4 1.0 MPa, respectively. Under control condition, shoot dry weight of cultivar ESW-9525 was maximum i.e. (14.09

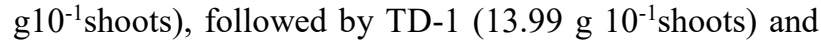
IBWSN-1010 (13.55 g10 ${ }^{-1}$ shoots). While, minimum shoot dry weight was observed in cultivars Khirman, Chakwal86 and IBWSN-1025 (12.97, 12.71 and $8.58 \mathrm{~g} 10^{-}$ ${ }^{1}$ shoots), respectively. The maximum shoot dry weight was recorded in cultivar Khirman (11.28 g10 ${ }^{-1}$ shoots), followed by Chakwal-86 and TD-1 as (9.25 and $8.32 \mathrm{~g}$ $10^{-1}$ shoots), at $-1.0 \mathrm{MPa}$. The other cultivar were also showing better SDW, was IBWSN-1010and IBWSN-

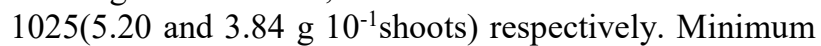

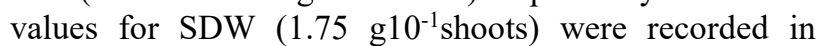
cultivar ESW-9525, respectively.

Root dry weight (g 10-1 roots): Results revealed that significant decrease with increasing water stress. High water stress condition (-1.0MPa) there was comparatively higher reduction in root dry weight with increasing water stress of the growing media. Mean values for root dry weight in different treatments were observed such as

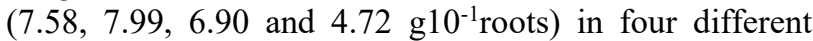
treatments of PEG viz T1 control (0), -T2 0.5 , T3 -0.75 and $\mathrm{T} 4-1.0 \mathrm{MPa}$, respectively. Under control condition, root dry weight of cultivar IBWSN-1010 was maximum

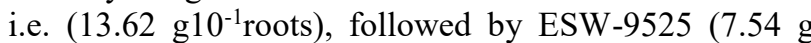
$10^{-1}$ roots), Khirman (6.85 g10 ${ }^{-1}$ roots) and Chakwal-86 (6.62 g10 $0^{-1}$ roots), whereas TD-1 (5.80 g $10^{-1}$ roots), whereas the minimum root dry weight were recorded in cultivar IBWSN-1025 (5.06 g 10-1 roots), respectively. Under highest osmotic stress $(-1.0 \mathrm{MPa})$ condition, root dry weight of cultivar Khirman was maximum i.e. (6.22 g $10^{-1}$ roots), followed by IBWSN-1010, TD-1 and Chakwal-86 (5.82, 5.35 and 4.74 g10-1 roots), while minimum root dry weight was observed in cultivar IBWSN-1025 and ESW-9525 (3.34 and 2.87 g10 $^{-1}$ roots), respectively. The decreasing trend in root and shoot dry weight was also reported by other researchers (Kamran et al., 2009; Ahmad et al., 2013; Marcińska et al., 2013) who found that water stress had a significant effect on root and shoot dry matter production.

Table.1 b. Mean value for various morphological traits of wheat cultivars at seedling stage under osmotic stress (PEG 6000).

\begin{tabular}{|c|c|c|c|c|c|c|c|c|c|}
\hline \multicolumn{10}{|c|}{ Effect of peg on different drought levels on growth parameters of six wheat cultivars } \\
\hline \multicolumn{10}{|c|}{ Morphological parameters } \\
\hline \multirow[b]{2}{*}{ Parameter } & \multirow[b]{2}{*}{ PEG level } & \multicolumn{6}{|c|}{ Cultivars } & \multirow[b]{2}{*}{ MEAN } & \multirow[b]{2}{*}{ LSD } \\
\hline & & IBWS-1010 & IBWS-1025 & TD-1 & ESW-9525 & Khirman & Chakwal-86 & & \\
\hline \multirow{5}{*}{ Shoot length } & Control & 16.68 & 13.93 & 12.88 & 15.86 & 17.01 & 16.22 & 15.43 & \multirow{5}{*}{0.99} \\
\hline & $0.5 \mathrm{MPA}$ & 16.43 & 14.93 & 12.78 & 12.56 & 17.60 & 15.69 & 15.00 & \\
\hline & $0.75 \mathrm{MPA}$ & 15.72 & 12.83 & 12.33 & 13.14 & 14.80 & 13.26 & 13.68 & \\
\hline & 1.0MPA & 5.29 & 5.06 & 9.68 & 4.09 & 12.36 & 12.56 & 8.17 & \\
\hline & Mean & 13.53 & 11.69 & 11.92 & 11.41 & 15.44 & 14.43 & & \\
\hline \multirow{5}{*}{ Root length } & Control & 10.62 & 8.98 & 5.34 & 12.04 & 12.92 & 11.81 & 10.29 & \multirow{5}{*}{1.65} \\
\hline & $0.5 \mathrm{MPA}$ & 13.64 & 14.11 & 10.30 & 12.22 & 17.12 & 14.58 & 13.66 & \\
\hline & $0.75 \mathrm{MPA}$ & 12.07 & 8.17 & 9.50 & 9.59 & 11.96 & 9.60 & 10.15 & \\
\hline & 1.0MPA & 4.83 & 5.13 & 8.67 & 4.82 & 9.33 & 10.02 & 7.13 & \\
\hline & Mean & 10.29 & 9.10 & 8.45 & 9.67 & 12.83 & 11.50 & & \\
\hline \multirow{5}{*}{ Shoot fresh wt } & Control & 90.04 & 69.33 & 72.01 & 92.01 & 102.86 & 102.67 & 88.15 & \multirow{5}{*}{9.24} \\
\hline & $0.5 \mathrm{MPA}$ & 86.64 & 62.46 & 53.53 & 49.48 & 85.77 & 91.86 & 71.62 & \\
\hline & $0.75 \mathrm{MPA}$ & 79.35 & 31.75 & 58.11 & 62.97 & 77.08 & 62.84 & 62.02 & \\
\hline & 1.0MPA & 27.59 & 19.73 & 54.63 & 10.82 & 52.87 & 57.22 & 37.14 & \\
\hline & Mean & 70.91 & 45.82 & 59.57 & 53.82 & 79.65 & 78.65 & & \\
\hline \multirow{5}{*}{ Root fresh wt } & Control & 71.76 & 40.55 & 34.46 & 50.06 & 40.00 & 35.29 & 45.35 & \multirow{5}{*}{5.99} \\
\hline & $0.5 \mathrm{MPA}$ & 82.36 & 42.76 & 44.27 & 16.18 & 44.69 & 41.01 & 45.21 & \\
\hline & $0.75 \mathrm{MPA}$ & 45.43 & 21.98 & 32.73 & 19.76 & 33.30 & 17.79 & 28.50 & \\
\hline & 1.0MPA & 27.22 & 14.89 & 25.56 & 8.07 & 25.03 & 13.60 & 19.06 & \\
\hline & Mean & 56.69 & 30.04 & 34.25 & 23.52 & 35.75 & 26.92 & & \\
\hline \multirow{5}{*}{ Shoot dry wt } & Control & 13.55 & 8.58 & 19.99 & 14.09 & 12.97 & 12.71 & 13.65 & \multirow{5}{*}{1.80} \\
\hline & $0.5 \mathrm{MPA}$ & 13.36 & 9.71 & 8.52 & 9.00 & 10.95 & 12.98 & 10.75 & \\
\hline & $0.75 \mathrm{MPA}$ & 12.37 & 5.62 & 10.12 & 9.67 & 11.83 & 13.16 & 10.46 & \\
\hline & 1.0MPA & 5.20 & 3.84 & 10.32 & 1.75 & 9.25 & 11.28 & 6.94 & \\
\hline & Mean & 11.12 & 6.94 & 12.24 & 8.63 & 11.25 & 12.53 & & \\
\hline
\end{tabular}




\begin{tabular}{|c|c|c|c|c|c|c|c|c|c|}
\hline \multirow{5}{*}{ Root dry wt } & Control & 13.62 & 5.06 & 5.80 & 7.54 & 6.85 & 6.62 & 7.58 & \multirow{5}{*}{1.01} \\
\hline & $0.5 \mathrm{MPA}$ & 12.42 & 5.95 & 6.83 & 6.61 & 6.61 & 9.52 & 7.99 & \\
\hline & $0.75 \mathrm{MPA}$ & 8.76 & 4.29 & 8.50 & 7.26 & 6.36 & 6.22 & 6.90 & \\
\hline & 1.0MPA & 5.82 & 3.34 & 5.35 & 2.87 & 4.74 & 6.22 & 4.72 & \\
\hline & Mean & 10.16 & 4.66 & 6.62 & 6.07 & 6.14 & 7.15 & & \\
\hline
\end{tabular}

Total chlorophyll content $\mathbf{m g} \mathrm{g}^{\mathbf{1}}$ fresh wt: Decreasing trend was recorded with increase of water stress, as depicted in table $2 \mathrm{~b}$. mean value for total chlorophyll content were recorded in different four treatment control (0), -T2 0.5, T3 -0.75 and T4 -1.0 MPa of PEG such as $0.43,0.40,0.35$ and 0.27 .as we observed the behaviors of different wheat cultivars on water stress, we found more total chlorophyll content in wheat cultivar Khirman, Chakwal-86 and ESW-9525 (0.75, 0.58 and $0.41 \mathrm{mg} \mathrm{g}^{1}$ fresh wt), followed by TD-1 and IBWSN-1025 (0.31 and0.29 $\mathrm{mg} \mathrm{g} 1$ fresh $\mathrm{wt})$. While the maximum value found in IBWSN-1010 (0.27 $\mathrm{mg} \mathrm{g}^{1}$ fresh wt) in control condition, respectively, at the highest water stress condition -1.0 $\mathrm{MPa}$ some of wheat cultivars performed well and others did not tolerate the stress. The higher reduction of total chlorophyll content in flag leaf was recorded in -1.0 MPa were found in the cultivar IBWSN1010 (0.12 $\mathrm{mg} \mathrm{g}^{1}$ fresh wt.) while the cultivar Khirman $\left(0.42 \mathrm{mg} \mathrm{g}^{1}\right.$ fresh $\left.\mathrm{wt}\right)$ produced maximum total chlorophyll content at high water stress level. Our results revealed that a decreasing trend was observed with increasing water stress. Similarly, (Li et al., 2006) observed that the values of chlorophyll content in drought tolerance cultivar s of barley were significantly higher than those in drought sensitive cultivar s under drought stress. It was also reported that the improvement of cultivar yield under drought stress has resulted from a more extended grain filling duration, a higher chlorophyll content, a more sustained turgor, or a combination of them (Paknejad et al., 2007). Drought stress produces changes in photosynthetic constituents (Anjum et al., 2003). Reduction of chlorophyll was the result of disappearance of thylakoid structures and chloroplast disintegration. (Cornoy et al., 1988) Khirman and Chakwal-86 exhibited better chlorophyll contents under moisture stress which showed their tolerance against drought. These results are supported by (Khayatnezhad et al., 2011), according to which chlorophyll contents of tolerant cultivars increased under drought stress.

Shoot/root potassium content $\mathbf{K}^{+}(\%)$ : To evaluate the ability of the six wheat cultivars and to distinguish the potassium and calcium concentrations, in roots and shoots, mean value for shoot $\mathrm{K}^{+}$were recorded in different four treatment control (0), -T2 0.5 , T3 -0.75 and T4 -1.0 MPa of PEG such as $0.91,1.56,1.45$ and 0.91 . The cultivars Khirman, TD-1 and ESW9525 reveled highest shoot $\mathrm{K}^{+}(1.05,1.03$ and $0.93 \%)$ under normal conditions followed by Chakwal-86, IBWSN-1010 and IBWSN-1025 (0.86, 0.84 and $0.75 \%)$, respectively. Increasing the water stress $-1.0 \mathrm{MPa}$, shoot $\mathrm{K}^{+}$ratio boost up in cultivar Khirman (1.66), Chakwal-86 (1.35) and TD-1(1.30) followed by, IBWSN-1025(0.61) and ESW9525 (0.38). Whereas the minimum ratio of shoot $\mathrm{K}^{+}$was marked in cultivar IBWSN-1010 (0.21), respectively. Mean value for root $\mathrm{K}^{+}$revealed under different treatments i.e., control (0), -T2 $0.5, \mathrm{~T} 3-0.75$ and T4 -1.0 $\mathrm{MPa}$ 0.43, 0.51, 0.74 and 0.54. Under control conditions, the cultivar ESW-9525 marked as maximum root $\mathrm{K}^{+}$as (0.46), moreover, minimum root $\mathrm{K}^{+}$was observed in IBWSN-1025 (0.35). Similarly, under higher osmotic stress level $(-1.0 \mathrm{MPa})$ the cultivar Khirman accumulated the maximum root $\mathrm{K}^{+}(0.91)$, while minimum accumulations of root $\mathrm{K}^{+}$were marked by cultivar IBWSN-1025 (0.42) respectively. This might be explained that higher $\mathrm{K}^{+}$concentration in plant growing medium offered more opportunity for roots absorbing $\mathrm{K}^{+}$ cellular membrane recovery enhanced $\mathrm{K}^{+}$conservation in plant tissues. The results are supported by the research carried out by (Wei et al., 2013) in his study, that adequate external $\mathrm{K}^{+}$significantly increased $\mathrm{K}^{+}$contents in both shoot and root of PEG6000-stressed.

Shoot/root calcium content $\mathrm{Ca}^{+}(\%)$ : The results of shoot and root calcium $\mathrm{Ca}^{+}$, mean value for shoot $\mathrm{Ca}^{+}$ were recorded as T1control (0), -T2 0.5, T3 -0.75 and T4 $-1.0 \mathrm{MPa}$ of PEG such as $0.87,1.11,1.02$ and 0.70 . The cultivar TD-1 had marked highest shoot $\mathrm{Ca}^{+}(1.21 \%)$, whereas Khirman accumulate less $\mathrm{Ca}^{+}$(0.62), respectively. whereas under high osmotic stress -1.0 $\mathrm{MPa}$, shoot $\mathrm{Ca}^{+}$ratio had accumulated more in cultivar TD-1 (1.13), while the ratio of $\mathrm{Ca}^{+}$observed less in cultivar ESW-9525 (0.33) different wheat cultivars accumulated calcium at their root and shoot as well, cross talk about the root calcium, the mean value for $\operatorname{root} \mathrm{Ca}^{+}$ reveled under different four treatments of PEG i.e., 0.52, $0.57,0.68$ and 0.58 . root $\mathrm{Ca}^{+}$was accumulate more by the cultivar IBWSN-1010 (0.53), while the less root $\mathrm{Ca}^{+}$had marked by the cultivar IBWSN-1025 (0.49) under controlled conditions. Similarly under higher osmotic stress level $(-1.0 \mathrm{MPa})$ the cultivar Khirman accumulated the maximum root $\mathrm{Ca}^{+}(0.66)$, while minimum accumulations of root $\mathrm{Ca}^{+}$were marked by cultivar ESW9525 (0.40), respectively. The study depicted that accumulation of root/ for shoot calcium there was varietal difference. Same results were found by (Mujtaba et al., 2016) in his study, he mentioned that PEG 6000 ratio was not significantly affected on Root $\mathrm{K}^{+} / \mathrm{Ca}^{+}$by osmotic stress. It was observed by (Mujtaba et al., 2016) in his study, where he reported that Root $\mathrm{K}^{+} / \mathrm{Ca}^{+}$ratio was not significantly affected by osmotic stress. 
Table 2b. Mean value for various physiological traits of wheat cultivars at seedling stage under osmotic stress (PEG 6000).

\begin{tabular}{|c|c|c|c|c|c|c|c|c|c|}
\hline \multicolumn{10}{|c|}{ Physiological parameters } \\
\hline \multirow{2}{*}{ Parameter } & \multirow{2}{*}{ PEG level } & \multicolumn{6}{|c|}{ Cultivars } & \multirow{2}{*}{ MEAN } & \multirow{2}{*}{ LSD 0.05} \\
\hline & & IBWS-1010 & IBWS-1025 & TD-1 & ESW-9525 & Khirman & Chakwal-86 & & \\
\hline \multirow{5}{*}{ Total chlorophyll content } & CONTROL & 0.272 & 0.289 & 0.3087 & 0.4132 & 0.7467 & 0.5767 & 0.434383 & \multirow{5}{*}{14.2} \\
\hline & $0.5 \mathrm{MPA}$ & 0.2577 & 0.1937 & 0.2713 & 0.3987 & 0.722 & 0.5417 & 0.397517 & \\
\hline & $0.75 \mathrm{MPA}$ & 0.244 & 0.1937 & 0.2737 & 0.3697 & 0.622 & 0.3697 & 0.345467 & \\
\hline & 1.0MPA & 0.121 & 0.1733 & 0.2613 & 0.2403 & 0.4243 & 0.4023 & 0.270417 & \\
\hline & Mean & 0.223675 & 0.212425 & 0.2788 & 0.355475 & 0.62875 & 0.4726 & & \\
\hline \multirow{5}{*}{ Shoot $\mathrm{K}^{+} \%$} & CONTROL & 0.8417 & 0.7542 & 1.025 & 0.9333 & 1.0542 & 0.8583 & 0.911117 & \multirow{5}{*}{18.51} \\
\hline & $0.5 \mathrm{MPA}$ & 1.4125 & 1.5833 & 1.7083 & 1.8208 & 1.625 & 1.2667 & 1.569433 & \\
\hline & $0.75 \mathrm{MPA}$ & 1.2158 & 0.7333 & 1.1808 & 1.8583 & 1.8667 & 1.8917 & 1.457767 & \\
\hline & 1.0MPA & 0.2083 & 0.6083 & 1.2958 & 0.3792 & 1.6583 & 1.35 & 0.91665 & \\
\hline & Mean & 0.919575 & 0.919775 & 1.3025 & 1.2479 & 1.55105 & 1.341675 & & \\
\hline \multirow{5}{*}{ Root $\mathrm{K}^{+} \%$} & CONTROL & 0.3583 & 0.35 & 0.5333 & 0.4625 & 0.4375 & 0.45 & 0.431933 & \multirow{5}{*}{20.86} \\
\hline & $0.5 \mathrm{MPA}$ & 0.4125 & 0.4167 & 0.7042 & 0.525 & 0.475 & 0.5333 & 0.511117 & \\
\hline & $0.75 \mathrm{MPA}$ & 0.4 & 0.6125 & 0.8958 & 0.7625 & 0.7 & 1.1083 & 0.746517 & \\
\hline & 1.0MPA & 0.4417 & 0.4208 & 0.5375 & 0.4542 & 0.9125 & 0.5 & 0.54445 & \\
\hline & Mean & 0.403125 & 0.45 & 0.6677 & 0.55105 & 0.63125 & 0.6479 & & \\
\hline \multirow{5}{*}{ Shoot $\mathrm{ca}^{+} \%$} & CONTROL & 1.0458 & 0.9958 & 1.2083 & 0.6667 & 0.6167 & 0.6833 & 0.869433 & \multirow{5}{*}{13.19} \\
\hline & $0.5 \mathrm{MPA}$ & 1.3042 & 1.5292 & 1.4417 & 0.7158 & 0.8875 & 0.775 & 1.1089 & \\
\hline & $0.75 \mathrm{MPA}$ & 1.1458 & 1.3083 & 1.0792 & 0.9133 & 0.8542 & 0.8183 & 1.01985 & \\
\hline & 1.0MPA & 0.5708 & 0.7708 & 1.125 & 0.325 & 0.7833 & 0.6458 & 0.70345 & \\
\hline & Mean & 1.01665 & 1.151025 & 1.2136 & 0.6552 & 0.785425 & 0.7306 & & \\
\hline \multirow{5}{*}{ Root $\mathrm{ca}^{+} \%$} & CONTROL & 0.5292 & 0.4917 & 0.5458 & 0.5042 & 0.5375 & 0.5167 & 0.52085 & \multirow{5}{*}{9.71} \\
\hline & $0.5 \mathrm{MPA}$ & 0.5208 & 0.5792 & 0.6542 & 0.6083 & 0.5208 & 0.5542 & 0.572917 & \\
\hline & $0.75 \mathrm{MPA}$ & 0.5 & 0.6167 & 0.6833 & 0.7375 & 0.6792 & 0.8542 & 0.678483 & \\
\hline & 1.0MPA & 0.5833 & 0.6208 & 0.6083 & 0.3958 & 0.6625 & 0.5917 & 0.577067 & \\
\hline & Mean & 0.533325 & 0.5771 & 0.6229 & 0.56145 & 0.6 & 0.6292 & & \\
\hline
\end{tabular}


Conclusion: In water deficits environments crops have developed biochemical and physiological approaches to tolerate. It is concluded from present research study that osmotic stress significantly reduced the shoot/root length fresh and dry weight all the tested wheat cultivars exhibited tolerance against osmotic stress under laboratory conditions. Among all the wheat cultivars tested Khirman, Chakwal-86 and TD-1 are the tolerant cultivars had the potential to perform better under drought conditions, whereas IBWSN-1010 and IBWSN1025 was moderate tolerant under water stress conditions. Furthermore the cultivars i.e. ESW-9525 is sensitive cultivar s under drought environment. Hence, it is recommended that these cultivars which performed better in water stress condition could increase production of arid lands.

\section{REFERENCES}

Abro, A. A., S. Memon, S. A. Abro, F. H. Magsi, A. A. Soomro, N. A. Mahar and B. H. Chang (2019). Influence of additional amino acids in growth of different wheat (Triticum aestivum L) cultivar s. J. Plant Nutr. 42(19): 2539-2551.

Ahmad, I., I. Khaliq, A. S. Khan and M. Farooq (2014). Screening of spring wheat (Triticum aestivum L.) cultivar $\mathrm{s}$ for drought tolerance on the basis of seedling traits. Pakistan J. Agric. Sci. 51(2): 367-372.

Ahmad, M., G. Shabbir, N. Minhas and M. K. N. Shah (2013). Identification of drought tolerant wheat cultivar $\mathrm{s}$ based on seedling traits. Sarhad. J. Agric. 29(1): 21-27.

Ahmed, H., A. S. Khan, S. H. Khan and M.Kashif (2017). Genome wide allelic pattern and genetic diversity of spring wheat cultivar s through SSR markers. Int. J. Agric. Biol. (19): 1559-1565.

Almaghrabi, O. A. (2012). Impact of drought stress on germination and seedling growth parameters of some wheat cultivars. Life sci. J. 9(1): 590-598.

Almansouri, M., J.M. Kinet and S. Lutts (2001). Effect of salt and osmotic stresses on germination in durum wheat (Triticum durum Desf.). Plant. and soil. 231(2): 243-254.

Amrutkar, P. S and S. R. Patil (2013). Automotive radiator performance-Review. Int. J. Eng and Adv. Tech. 2(3): 563-565.

Anjum, F., M.Yaseen, E. Rasul, A. Wahid and S. Anjum (2003). Water stress in barley (Hordeum vulgare L.). II. Effect on chemical composition and chlorophyll contents. Pakistan J. Agric. Sci. 40: 45-49.

Bayoumi, T., M. H. Eid and E. Metwali (2008). Application of physiological and biochemical indices as a screening technique for drought tolerance in wheat cultivar s. Afr. J. Bot. 7(14).
Chachar, M., N. Chachar, S.Chachar, Q. Chachar, S. Mujtaba and A.Yousafzai (2014). In-vitro screening technique for drought tolerance of wheat (Triticum aestivium L.) cultivar s at early seedling stage. J. Agric. Tech. 10(6): 1439-1450.

Conroy, J. P., J. M. Virgona, R. M. Smillie and E. W. Barlow (1988). Influence of drought acclimation and $\mathrm{CO} 2$ enrichment on osmotic adjustment and chlorophyll a fluorescence of sunflower during drought. Plant physiol. 86(4): 1108-1115.

Dhanda, S., G. Sethi and R. Behl (2004). Indices of drought tolerance in wheat cultivar $s$ at early stages of plant growth. J. Agro. and crop sci. 190(1): 6-12.

Foito, A., S. L. Byrne, T. Shepherd, D. Stewart and S.Barth (2009). Transcriptional and metabolic profiles of Lolium perenne $L$. cultivar $s$ in response to a PEG-induced water stress. Plant Biotech. J. 7(8): 719-732.

Gomez, K. A and A. A.Gomez (1984). Statistical procedures for agricultural research: John Wiley and Sons.

Iqbal, M and M. Ashraf (2007). Seed treatment with auxins modulates growth and ion partitioning in salt stressed wheat plants. J. Int. Plant. Bio. 49(7): 1003-1015.

Jajarmi, V. (2009). Effect of water stress on germination indices in seven wheat cultivar. W. Acad. of Sci. Eng. and Tech. 49: 105-106.

Kamran, M., M. Shahbaz, M. Ashraf and N. A. Akram (2009). Alleviation of drought-induced adverse effects in spring wheat (Triticum aestivum L.) using proline as a pre-sowing seed treatment. Pakistan J. Bot. 41(2): 621-632.

Kaya, M. D., G.Okçu, M. Atak, Y. Cıkılı and Ö. Kolsaric1 (2006). Seed treatments to overcome salt and drought stress during germination in sunflower (Helianthus annuus L.). Eur. J. Agro. 24(4): 291-295.

Khajeh Hosseini, M., A. Powell and I. Bingham (2000). The effects of reduced water availability and salinity on the early seedling growth of soybean. Paper presented at the Third Int. Crop Sci. Congress.

Khayatnezhad, M., R. Gholamin, S. Jamaati-e-Somarin and R. Zabihi-e-Mahmoodabad (2011). The leaf chlorophyll content and stress resistance relationship considering in Corn cultivars (Zea. Mays). Adv. Env. Bio. 118-123.

Khodarahmpour, Z. (2011). Effect of drought stress induced by polyethylene glycol (PEG) on germination indices in corn (Zea mays L.) hybrids. Afri. J. Biotech. 10(79): 18222-18227.

Li, R.-h., P.-g. Guo, B. Michael, G. Stefania and C. Salvatore (2006). Evaluation of chlorophyll content and fluorescence parameters as 
indicators of drought tolerance in barley. Agric. Sci. China. 5(10): 751-757.

Manoj, K and D.Uday (2007). In vitro screening of tomato cultivar $\mathrm{s}$ for drought resistance using polyethylene glycol. Afri. J. of Biotech. 6(6).

Maqsood, M., M. A. Shehzad, S. Ahmad and S.Mushtaq (2012). Performance of wheat (Triticum aestivum L.) cultivar $\mathrm{s}$ associated with agronomical traits under water stress conditions. Asian J. Pharmaceutical and Bio. Res. (AJPBR), 2(1).

Marcińska, I., I. Czyczyło-Mysza, E. Skrzypek, M. Filek, S.Grzesiak, M. T. Grzesiak and K. Dziurka, (2013). Impact of osmotic stress on physiological and biochemical characteristics in drought-susceptible and drought-resistant wheat cultivar s. Acta physio. plantarum. 35(2): 451461.

Metwali, E., M. H. Eid and T. Y. Bayoumi (2011). Agronomical traits and biochemical genetics markers associated with salt tolerance in wheat cultivars (Triticum aestivum L). Australian J. Basic and Appl. Sci. 5(5): 174-183.

Mujtaba, S. M., S. Faisal, M. A. Khan, S. Mumtaz and B. Khanzada (2016). Physiological studies on six wheat (Triticum aestivum L.) genotypes for drought stress tolerance at seedling stage. Agri. Res. \& Tech. 1(2): 1-6.

Noorka, I. R., A. Batool, S. Rauf, J.Teixeira da Silva and E. Ashraf (2013). Estimation of heterosis in wheat (Triticum aestivum L.) under contrasting water regimes. Int. J. Plant Breeding. 7(1): 5560.

Noorka, I. R and I. Khaliq (2007). An efficient technique for screening wheat (Triticum aestivum L.) germplasm for drought tolerance. Pakistan J. Bot. 39(5): 1539-1546.

Okçu, G., M. D. Kaya and M. Atak (2005). Effects of salt and drought stresses on germination and seedling growth of pea (Pisum sativum L.). Turkish J. Agric. and forestry. 29(4): 237-242.

Oneto, C. D., M. E. Otegui, I. Baroli, A. Beznec, P. Faccio, E. Bossio and D.Lewi (2016). Water deficit stress tolerance in maize conferred by expression of an isopentenyltransferase (IPT) gene driven by a stress-and maturation-induced promoter. J. biotech. 220: 66-77.

Paknejad, F., M. Nasri, H. T. Moghadam, H. Zahedi and M. J.Alahmadi (2007). Effects of drought stress on chlorophyll fluorescence parameters, chlorophyll content and grain yield of wheat cultivars. J. Bio. Sci., 7(6): 841-847.

Pan, X., Y. Wang, G. Wang, Q. Cao and J Wang (2002). Relationship between growth redundancy and size inequality in spring wheat populations mulched with clear plastic film. Acta Phytoecol. Sinica. 26: 177-184.

Qayyum, A., A. Razzaq, M. Ahmad and M. A. Jenks (2011). Water stress causes differential effects on germination indices, total soluble sugar and proline content in wheat (Triticum aestivum L.) cultivar s. Afric. J. Biotech. 10(64): 1403814045.

Rauf, M., M. Munir, M. ul Hassan, M. Ahmad and M. Afzal (2007). Performance of wheat cultivar s under osmotic stress at germination and early seedling growth stage. Afric. J. Biotech. 6(8).

Wang, W., B. Vinocur and A. Altman (2003). Plant responses to drought, salinity and extreme temperatures: towards genetic engineering for stress tolerance Planta. 218(1): 1-14.

Wei, J., C. Li, Y. Li, G. Jiang, G. Cheng and Y. Zheng (2013). Effects of external potassium (K) supply on drought tolerances of two contrasting winter wheat cultivars. Plos one. 8(7): 69737.

Zhu, J.-K. (2002). Salt and drought stress signal transduction in plants. Annu. rev. plant bio.53(1): 247-273. 